UDC 65.01:334

\title{
Bortnikova M.
}

\section{FEATURES OF THE FORMATION OF A COMPREHENSIVE CONSULTING PROJECT FOR MACHINE-BUILDING ENTERPRISE}

\begin{abstract}
The graphic model of the formation of applied toolkit of diagnostics consulting projects for machine-building enterprises has been developed. A specification of a comprehensive consulting project is proposed. A toolkit of decomposing the enterprise management system is outlined to identify areas of concern that can be the subject of consulting. Control system elements are presented. The criteria for the involvement of consultants and criteria for the successful implementation of the consulting project are presented. A payment mechanism for consulting services provided within the framework of a comprehensive project has been formed.
\end{abstract}

Keywords: model, mechanism, toolkit, diagnostics of consulting projects, identification, specification, decomposition.

Problem definition. Domestic machinebuilding enterprises will sooner or later face the need for a sharp expansion of the practice of using consulting projects, but those who have already begun work in this direction will win because there is a significant time lag of obtaining the result.

A significant factor in the resistance of managers of machine-building enterprises to the development of consulting projects is a lack of understanding of what areas of activity and how long it will be possible to develop on the basis of implemented and diagnosed projects.

Analysis of the latest researches and publications. Today in the scientific literature there is a considerable number of approaches to the diagnosis of various spheres of enterprise activity [15]. According to the results of the research, a number of problems of methodological and applied nature regarding the diagnostic of consulting projects have been identified. Taking into account the aforesaid, there is a need to justify the features of the formation of a comprehensive consulting project for a machine building enterprise within the applied toolkit of diagnostic.

Formulating the goals of the article. The main goal of the research is to highlight the features of the formation of a comprehensive consulting project for a machine-building enterprise.

Setting forth the research basic material. The formation of applied toolkit of diagnostics consulting projects for machine-building enterprises begins with the fact that we have to determine what impact consultants will have on the activities of the company in the current and prospective sections. To overcome the multivariate problem of consulting projects in terms of their diagnosis and implementa-

(C) Bortnikova Maryana, senior lecturer in foreign trade and customs activities department, Lviv Polytechnic National University, Lviv, tel.: +380322582725, e-mail: knysh.maryana@gmail.com tion, we propose to use the principle of decomposition of complex systems. This means that on the example of several concrete machine-building enterprises we choose problem areas of management and select already implemented consulting projects that could partially satisfy the existing problems.

Each management area in each of the selected enterprises is divided into elementary business processes, and each one is implemented by someone else's consulting project - at the stage and phase of design and implementation. The combination of elementary business processes of enterprises and the project stages of the implemented consulting projects will make it possible to identify those links and modules of future consulting projects that can be proposed for the next practical implementation. For example, if we have information on the use of consulting projects in the field of information technology and communication systems of PJSC "Motor Sich", PJSC "Kharkiv Tractor Plant", PJSC "Mayak" and others, then their diagnostics at different stages of operation will allow to distinguish those elements, Which will guarantee the result in practice of PJSC "Lviv Locomotive Repair Plant", PJSC "Iskra" or PJSC "Concern Electron" even under different starting conditions.

Since the process of creating application tools for diagnosing consulting projects is complex and multilevel, we will construct a graphic model for its visualization, the first unit of which will be the mechanism for identifying the impact of consulting projects on the activities of enterprises (Figure 1).

It should be noted that the concept of "diagnosed consulting projects" includes projects at all stages of their development and implementation. Before designing, we diagnose the potential of consulting projects to improve a certain subject area; at the stage of selecting a consulting firm, we diagnose the potential of consulting projects executed by various developers; at the stages of designing, testing and implementation - to diagnose the parameters of 
consulting projects and their changes. Finally, after we diagnose the duration and stability of the results, the full implementation of the consulting projects, time lags, side effects, etc.

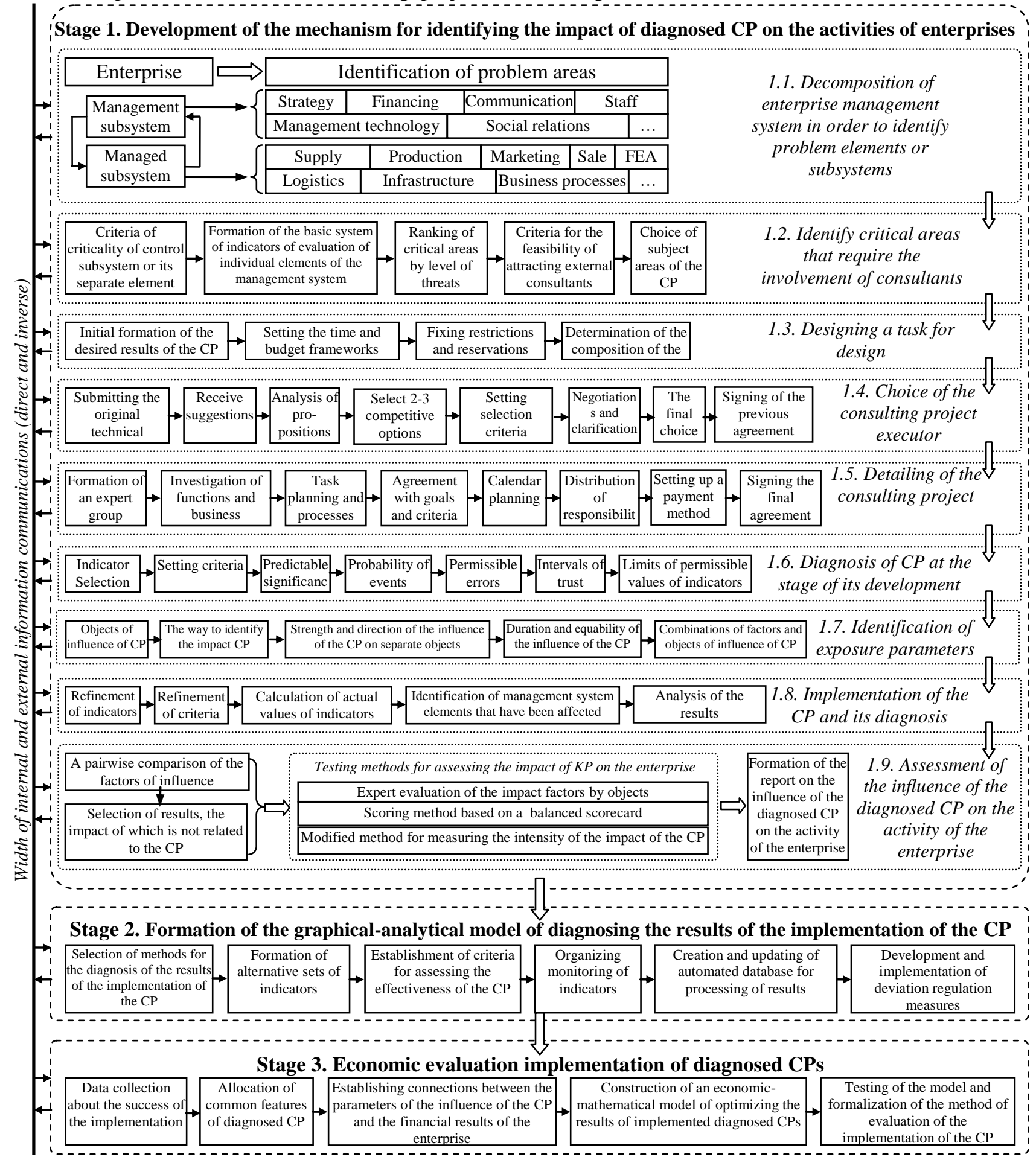

Fig.1 Graphic model of the formation of applied toolkit for diagnostics consulting projects for machine-building enterprises*

* Developed by the author

The decomposition of the enterprise management system involves the allocation of problem areas of control and managed subsystems, which are subsequently tested for the need or necessity for external consultants to be involved. Which of the elements of the management system will turn out to be problematic sometimes difficult to determine from the results of work units, therefore, we propose to investigate the structural elements and business processes for the purpose of compliance with critical criteria, including a sharp decrease in the norm of manageability, deterioration of current performance indicators, deterioration of overall efficiency, the presence of unnecessary or unproductive links between elements of the control system, etc. (Table 1). 
Decomposition of enterprise management system and allocation of problem areas (for example, PJSC "Iskra")*

\begin{tabular}{|c|c|c|c|c|c|c|c|c|c|c|c|}
\hline \multirow[b]{3}{*}{ Elements of the control system } & \multicolumn{5}{|c|}{ Characteristics of control system elements } & \multicolumn{5}{|c|}{$\begin{array}{l}\text { Criteria for engaging } \\
\text { consultants }\end{array}$} & \multirow{3}{*}{ 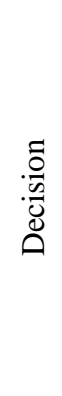 } \\
\hline & \multirow{2}{*}{ 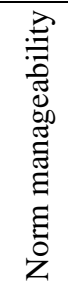 } & \multirow{2}{*}{ 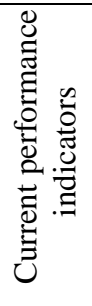 } & \multirow{2}{*}{ 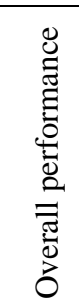 } & \multirow[b]{2}{*}{ 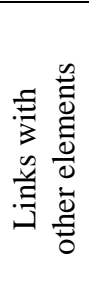 } & \multirow[b]{2}{*}{ 䒕 } & \multicolumn{3}{|c|}{ Reserves } & \multicolumn{2}{|c|}{ Threats } & \\
\hline & & & & & & $\stackrel{\varrho}{E}$ & 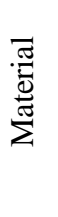 & 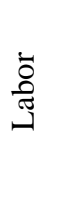 & 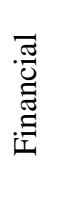 & 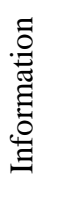 & \\
\hline \multicolumn{12}{|c|}{ 1. The manager subsystem } \\
\hline Strategic planning & $\equiv$ & $\downarrow$ & $\downarrow \downarrow$ & $\downarrow \downarrow$ & $\mathrm{M}_{1}$ & - & $\equiv$ & $\equiv$ & $\equiv$ & - & yes \\
\hline Financing activities & $\equiv$ & $\downarrow$ & $\downarrow$ & 0 & $\mathrm{M}_{4}$ & $\equiv$ & - & $\equiv$ & - & + & no \\
\hline Relationship of property & $\equiv$ & 0 & 0 & $\downarrow$ & $\mathrm{M}_{5}$ & $\equiv$ & $\equiv$ & + & + & + & no \\
\hline Communication system & $\equiv$ & $\downarrow$ & $\downarrow \downarrow$ & $\downarrow$ & $\mathrm{M}_{2}$ & - & - & - & - & - & yes \\
\hline $\begin{array}{l}\text { Selection of management } \\
\text { personnel }\end{array}$ & $\equiv$ & $\uparrow$ & $\uparrow$ & 0 & $\mathrm{M}_{6}$ & - & - & - & - & + & yes \\
\hline Social interactions & $\equiv$ & 0 & 0 & $\uparrow$ & $\mathrm{M}_{7}$ & $\equiv$ & - & + & - & + & no \\
\hline Management technology & $\equiv$ & $\downarrow$ & $\downarrow$ & $\downarrow$ & $\mathrm{M}_{3}$ & - & - & - & - & + & yes \\
\hline \multicolumn{12}{|c|}{ 2.1. The managed subsystem - functional service } \\
\hline Tactical Planning & $\downarrow$ & $\downarrow$ & $\downarrow$ & $\downarrow \downarrow$ & $\mathrm{F}_{1}$ & - & - & - & - & - & yes \\
\hline Accounting & 0 & $\uparrow$ & $\uparrow$ & $\uparrow$ & $\mathrm{F}_{7}$ & + & + & + & + & + & no \\
\hline Legal support & 0 & $\uparrow \uparrow$ & $\uparrow$ & $\uparrow$ & $\mathrm{F}_{8}$ & + & + & + & + & - & no \\
\hline Security system & 0 & $\uparrow$ & $\uparrow$ & $\uparrow$ & $\mathrm{F}_{6}$ & - & + & + & + & - & no \\
\hline Supply & 0 & $\uparrow$ & $\uparrow$ & 0 & $\mathrm{~F}_{5}$ & - & + & + & + & + & no \\
\hline Marketing and advertising & 0 & 0 & 0 & $\uparrow$ & $\mathrm{F}_{4}$ & + & + & + & + & - & no \\
\hline Sales and after-sales service & $\downarrow$ & $\downarrow$ & 0 & $\uparrow$ & $\mathrm{F}_{2}$ & $\equiv$ & + & + & - & + & no \\
\hline Foreign economic activity & $\downarrow$ & $\downarrow$ & 0 & $\uparrow$ & $\mathrm{F}_{3}$ & + & + & + & - & + & no \\
\hline \multicolumn{12}{|c|}{ 2.2. The managed subsystem - production } \\
\hline $\begin{array}{l}\text { Technical preparation of } \\
\text { production }\end{array}$ & 0 & 0 & $\uparrow$ & $\uparrow$ & $\mathrm{P}_{7}$ & $\equiv$ & + & + & - & + & no \\
\hline Technological support & 0 & $\downarrow$ & 0 & 0 & $\mathrm{P}_{5}$ & + & - & + & - & - & yes \\
\hline Engineering support & $\downarrow$ & $\downarrow$ & 0 & 0 & $\mathrm{P}_{4}$ & + & - & - & - & - & yes \\
\hline
\end{tabular}

\begin{tabular}{|c|c|c|c|c|c|c|c|c|c|c|c|}
\hline Primary production & 0 & $\uparrow$ & $\uparrow$ & 0 & $\mathrm{P}_{8}$ & + & + & + & + & + & no \\
\hline auxiliary production & $\downarrow$ & 0 & $\uparrow$ & $\uparrow$ & $\mathrm{P}_{6}$ & + & + & + & + & + & no \\
\hline Technical control & 0 & $\uparrow$ & $\uparrow$ & $\uparrow \uparrow$ & $\mathrm{P}_{9}$ & + & + & + & + & + & no \\
\hline Occupational safety and health & 0 & 0 & 0 & $\downarrow$ & $\mathrm{P}_{3}$ & $\equiv$ & + & + & + & + & no \\
\hline $\begin{array}{l}\text { Warehousing, transport and } \\
\text { logistics }\end{array}$ & 0 & $\downarrow$ & $\downarrow$ & 0 & $\mathrm{P}_{2}$ & - & + & + & - & + & no \\
\hline $\begin{array}{l}\text { Repair and instrumental } \\
\text { economy }\end{array}$ & $\downarrow$ & $\downarrow$ & $\downarrow$ & 0 & $\mathrm{P}_{1}$ & - & + & + & + & + & no \\
\hline
\end{tabular}
economy

2.3. The managed subsystem is an intellectual component

\begin{tabular}{|l|c|c|c|c|c|c|c|c|c|c|c|}
\hline Recruitment & $\downarrow$ & 0 & 0 & 0 & $\mathrm{I}_{5}$ & - & $\equiv$ & - & - & - & yes \\
\hline System of motivation of labor & 0 & $\uparrow$ & 0 & 0 & $\mathrm{I}_{6}$ & $\equiv$ & - & + & + & + & $\mathrm{no}$ \\
\hline $\begin{array}{l}\text { Advanced training and } \\
\text { retraining }\end{array}$ & $\downarrow$ & $\downarrow$ & $\downarrow$ & 0 & $\mathrm{I}_{3}$ & - & - & - & $\equiv$ & $\equiv$ & yes \\
\hline Corporate culture & 0 & $\uparrow$ & $\uparrow$ & 0 & $\mathrm{I}_{7}$ & $\equiv$ & + & + & - & - & no \\
\hline Social infrastructure & 0 & $\uparrow$ & $\uparrow$ & $\uparrow$ & $\mathrm{I}_{8}$ & - & - & + & - & + & no \\
\hline R \& D and innovation & $\downarrow$ & $\downarrow$ & $\downarrow$ & $\downarrow$ & $\mathrm{I}_{2}$ & - & - & - & - & - & yes \\
\hline Internal communications & $\downarrow$ & $\downarrow$ & 0 & 0 & $\mathrm{I}_{4}$ & - & - & - & - & - & yes \\
\hline Patent-licensing activity & $\downarrow$ & $\downarrow$ & $\downarrow \downarrow$ & $\downarrow$ & $\mathrm{I}_{1}$ & - & - & - & - & - & yes \\
\hline
\end{tabular}

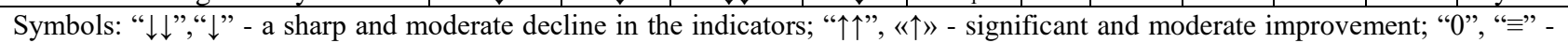
indicators are not changed or are not considered; "+" - the resource is sufficient, the threat is insignificant, "-" - the resource is scarce, the threat is large, "E” - resource or threat is not a criterion.

* Developed by the author 
Characteristics of control system elements are determined on the basis of the average weighted value of the key indicators for each subsystem or its element. For a managed subsystem, these are quantitative indicators, and for the controller combined on the basis of technology BSC. We consider the set of mentioned indicators to be basic. With regard to the norm of controllability - it reflects the response of the elements of the controlled subsystem to the effects of the control subsystem and is also determined by the relevant indicators. Links with other elements are manifested as information exchange and the presence of deviations in the internal workflow system.

If a certain characteristic of the control deviates in the range of $\pm 5 \%$, then such a change is considered moderate and is denoted by the appropriate symbols $\uparrow$ or $\downarrow$, depending on the direction of the change. Deviations over 5\% are considered significant (“ $\uparrow$ ” or “ $\downarrow \downarrow$ ”), and deviations by the amplitude $<1 \%$ are not taken into account at this stage ("0"). There is no control for the elements of the control subsystem (“””).

Based on the research results, for each group of elements of the management system, ranks are established that reflect the priority of regulation. In the control subsystem we have seven elements selected, of which the most problematic are strategic planning (M1), communication system (M2) and control technology (M3). Elements of a controlled subsystem, we divided into 3 subgroups - functional service (the weakest links F1 - tactical planning, F2 sales and after-sales service, F3 - foreign economic activity); Production (most problems in elements B1 - repair and instrumental economy, B2 warehousing, transport and logistics, B3 - safety and health and safety equipment); Intellectual component (the worst features show elements I1 patent and licensing activity, I2 - research and development, innovations, I3 - advanced training and retraining).

In general, 25 elements of the managed PJSC "Iskra" system have been analyzed, but most of the problem elements of the management system for attracting external consultants do not require, provided that they are adequately funded and properly organized, they can be completely corrected on their own. In order to identify problem areas that require external consulting, we introduce 5 criteria: three resources (in terms of time, material costs and labor intensity) and two in terms of threats (financial and informational). If an enterprise is limited in time, material resources or labor, or further delay with the solution of an identified management problem, there are major financial or informational threats, then we put the sign "." in the appropriate column. In the case of resource adequacy and low level of threats, there is a "+" sign, and if the resource or threat is not a criterion for attracting consultants, the sign " $\equiv "$ ". The decision to involve consultants to solve problems of certain elements of the management system is based on the ranking of their critical characteristics, combined with the consideration of these criteria.

Based on the results of the diagnostics of individual elements of the control and managed control subsystems, it is possible to select the subject areas of the future consulting project. In the case of PJSC "Iskra" it is strategic planning, personnel work and communication. These three subject areas indirectly cover virtually all the problem elements of the enterprise management system, as can be seen from the proposed specification of an integrated consulting project (Table 2). In the case of a large engineering company, the complex solution to the problems identified is optimal, since it allows you to concentrate resources and work with one major consulting firm. For smaller companies it is unrealistic, they will have to consistently diagnose and implement several consulting projects.

In fact, the given specification is the primary formulation of the desired result and, together with the establishment of the time and budget framework, certain restrictions and warnings of information and security; it is possible to begin to determine the composition of the executives of the consulting project. All together, this is the task of designing, at this stage we must determine the number of involved consulting firms, individual consultants, involved in their own specialists, etc. There are a lot of options, especially given the insufficient level of development of the consulting services market.

The next stage is the choice of the consultant's executor and it turned out to be difficult to find information on potential counterparties. Unlike Western countries, in Ukraine there is no professional association of consultancy providers, nor a register of certified specialists that can be involved in management consulting. Moreover, some consulting firms are in fact highly specialized, but in their information releases, they claim that they are capable of performing complex consulting projects. If the machine-building company does not have the experience of working with consulting firms, then either the largest players in the market for such services should look or seek a competent management consulting expert in a research or higher education institution. Such an expert will be able to assess the task setting for designing and recommend consulting firms that are capable of performing a similar consulting project. 
Table 2

The specification of a comprehensive consulting project for PJSC "Iskra"*

\begin{tabular}{|c|c|c|c|c|c|}
\hline \multirow[t]{2}{*}{ Tasks } & \multirow[t]{2}{*}{ Priorities } & \multicolumn{2}{|c|}{$\begin{array}{l}\text { Duration of work } \\
\text { execution }\end{array}$} & \multirow{2}{*}{$\begin{array}{l}\text { Criteria for the success } \\
\text { of implementation }\end{array}$} & \multirow[t]{2}{*}{ Valuation indicators } \\
\hline & & Designing & Implementation & & \\
\hline \multicolumn{6}{|c|}{ 1. Improvement of the strategic planning system in part: } \\
\hline $\begin{array}{l}\text { - information provision of } \\
\text { strategic planning }\left(S_{1}\right)\end{array}$ & 1 & $\begin{array}{c}1 \\
\text { month }\end{array}$ & 1 month & $\begin{array}{l}\text { Increase the level of } \\
\text { attainable goals }\end{array}$ & $\begin{array}{l}\text { Timing of tasks, norms of } \\
\text { expenditure of resources, } \\
\text { accuracy of forecasts }\end{array}$ \\
\hline $\begin{array}{c}- \text { research of the market of } \\
\text { machine-building products }\left(S_{2}\right)\end{array}$ & 2 & $\begin{array}{c}2 \\
\text { month }\end{array}$ & 3 month & $\begin{array}{l}\text { Availability of relevant } \\
\text { market information }\end{array}$ & $\begin{array}{l}\text { Market share, advance of } \\
\text { competitors }\end{array}$ \\
\hline $\begin{array}{l}\quad-\text { diversification of } \\
\text { activities, including in foreign } \\
\text { markets }\left(\mathrm{S}_{3}\right)\end{array}$ & 2 & $\begin{array}{c}3 \\
\text { month }\end{array}$ & 3 month & $\begin{array}{l}\text { Optimization of the } \\
\text { structure of activity }\end{array}$ & $\begin{array}{l}\text { Number and structure of } \\
\text { activities, their volumes }\end{array}$ \\
\hline $\begin{array}{l}\quad \text { - investment planning in } \\
\text { innovation development and } \mathrm{R} \\
\& \mathrm{D}\left(\mathrm{S}_{4}\right)\end{array}$ & 3 & $\begin{array}{c}2 \\
\text { month }\end{array}$ & 1 month & $\begin{array}{l}\text { Increasing the level of } \\
\text { innovation development }\end{array}$ & $\begin{array}{l}\text { Capital productivity of projects, } \\
\text { profitability of R \& D }\end{array}$ \\
\hline $\begin{array}{l}- \text { commercialization of } \\
\text { IPOs }\left(S_{5}\right)\end{array}$ & 3 & $\begin{array}{c}3 \\
\text { month }\end{array}$ & 3 month & $\begin{array}{l}\text { Increasing the level of } \\
\text { efficiency of intangible } \\
\text { assets }\end{array}$ & $\begin{array}{l}\text { Market value, volume and } \\
\text { profitability of intangible assets, } \\
\text { number of patents }\end{array}$ \\
\hline \multicolumn{6}{|c|}{ 2. Improvement of the system of work with the personnel in the part: } \\
\hline $\begin{array}{l}- \text { selection of managerial } \\
\text { personnel }\left(\mathrm{P}_{1}\right)\end{array}$ & 3 & $\begin{array}{c}2 \\
\text { month }\end{array}$ & 1 month & $\begin{array}{l}\text { Activation of strategy } \\
\text { implementation }\end{array}$ & $\begin{array}{l}\text { The turnover of managers, the } \\
\text { level of quality of decisions }\end{array}$ \\
\hline $\begin{array}{l}\text { - building a system of } \\
\text { personnel attestation }\left(\mathrm{P}_{2}\right)\end{array}$ & 3 & $\begin{array}{c}2 \\
\text { month }\end{array}$ & 1 month & $\begin{array}{l}\text { Activating the } \\
\text { fulfillment of goals and } \\
\text { objectives }\end{array}$ & $\begin{array}{l}\text { Labor productivity, staff } \\
\text { turnover }\end{array}$ \\
\hline $\begin{array}{l}\text { - development of advanced } \\
\text { training system }\left(\mathrm{P}_{3}\right)\end{array}$ & 3 & $\begin{array}{c}3 \\
\text { month }\end{array}$ & 1 month & Improved controllability & $\begin{array}{l}\text { Increase in the level of } \\
\text { intellectual activity }\end{array}$ \\
\hline $\begin{array}{l}- \text { development of a rotation } \\
\text { scheme for management } \\
\text { personnel and engineering staff } \\
\left(\mathrm{P}_{4}\right)\end{array}$ & 3 & $\begin{array}{c}3 \\
\text { month }\end{array}$ & 1 month & $\begin{array}{l}\text { Ensuring } \\
\text { interchangeability }\end{array}$ & $\begin{array}{l}\text { Increase in the share of } \\
\text { operational time }\end{array}$ \\
\hline $\begin{array}{l}\quad \text { - improvement of } \\
\text { information provision of } \\
\text { personnel services }\left(\mathrm{P}_{5}\right)\end{array}$ & 1 & $\begin{array}{c}2 \\
\text { month }\end{array}$ & 1 month & $\begin{array}{l}\text { Reducing the level of } \\
\text { conflict, the effect of } \\
\text { synergy }\end{array}$ & $\begin{array}{l}\text { Staff turnover, labor } \\
\text { productivity, }\end{array}$ \\
\hline \multicolumn{6}{|c|}{ 3. Improvement of the communications system in part: } \\
\hline $\begin{array}{l}\text { - development of the } \\
\text { concept of automation of } \\
\text { document circulation }\left(\mathrm{I}_{1}\right)\end{array}$ & 1 & $\begin{array}{c}2 \\
\text { month }\end{array}$ & 4 month & $\begin{array}{l}\text { Improving the quality of } \\
\text { document circulation }\end{array}$ & $\begin{array}{l}\text { Number of errors, error } \\
\text { correction time }\end{array}$ \\
\hline $\begin{array}{l}\quad \text { - formation of } \\
\text { requirements for the enterprise } \\
\text { information system }\left(\mathrm{I}_{2}\right)\end{array}$ & 1 & $\begin{array}{c}1 \\
\text { month }\end{array}$ & 1 month & $\begin{array}{l}\text { Improving the } \\
\text { functionality of the } \\
\text { information system }\end{array}$ & $\begin{array}{l}\text { The number of functions of the } \\
\text { information system, the level of } \\
\text { their use }\end{array}$ \\
\hline $\begin{array}{l}\quad \text {-improvement of } \\
\text { information protection means } \\
\left(\mathrm{I}_{3}\right)\end{array}$ & 1 & $\begin{array}{c}1 \\
\text { month }\end{array}$ & 3 month & $\begin{array}{l}\text { Increasing the level of } \\
\text { information security }\end{array}$ & $\begin{array}{l}\text { Number of unauthorized } \\
\text { accesses, reaction rate for } \\
\text { intervention }\end{array}$ \\
\hline
\end{tabular}

\section{* Developed by the author}

The practice of Western engineering companies shows that the initial number of potential performers can be arbitrary, often consulting firms offer their services in a preventive way in the hope of further obtaining an order. After sending the original technical specification to potential performers and analyzing their proposals, it is advisable to select no more than 2-3 competitive options, which will be considered in detail. The initial specification of the consulting project does not contain details, but gives a general idea of the needs of the customer and their proposed criteria for the success of the project. After selecting a few real offers for additional criteria (mainly the "price-expected result" or "runtimeefficiency" ratio), negotiations with potential performers are taking place, which results in the choice of a consulting firm and the signing of a protocol of intent or a contract for execution of the project Works The final contract for the implementation of an integrated consulting project at this stage is not signed, since the real detailed project does not exist yet, and it is quite possible that they will have to reject the project of one firm and return to negotiations with others.

Following the presentation of a consulting firm, a project developed by an expert group (mostly involving external experts) developed by the company conducts research on the functions and business processes that undergo changes as a result of the project implementation. If the results obtained satisfy the primary requirements, then the planning of tasks and processes, their coordination with the objectives of the enterprise and the criterion of business efficiency are carried out. All this becomes 
the basis for scheduling and distributing responsibilities among the participants in the process of implementing a consulting project. An important point in preparing a final contract is the establishment of the form and method of payment for the services rendered. On the one hand, world practice knows a lot of ways to pay for consulting services, but on the other - there are many grounds for conflicts and litigation regarding issues of financial obligations of the parties.

The choice of the form and method of payment for the provided consulting services and implemented consulting projects is the subject of agreements between the parties, and in the course of the project implementation, these agreements may be changed or partially violated as a result of the unchangeable force or change of the priorities of the customer and the executor in the case of the introduction of long-term integrated projects. Before entering the negotiations, each party must set the desired payment terms and the limits of those concessions that can be made. To do this, it is necessary to clearly present the features of different, especially specific, forms of payment consulting services, as well as to have an idea of the opportunities and threats that each of these forms. Based on the logic of the design process and the specifics of the domestic machine-building enterprises, we offer a three-step mechanism of payment for services of consulting firms, which will protect the performer from excessive costs in case of recognition of the project unsuccessful and will stimulate the performer to qualitative performance of each of the specified stages within the complex project. The payment mechanism should be tightly bound to the specification of an integrated consulting project and provide for the possibility of suspending funding if in the intermediate stages the diagnostic results do not meet the established criteria (Figure 2).

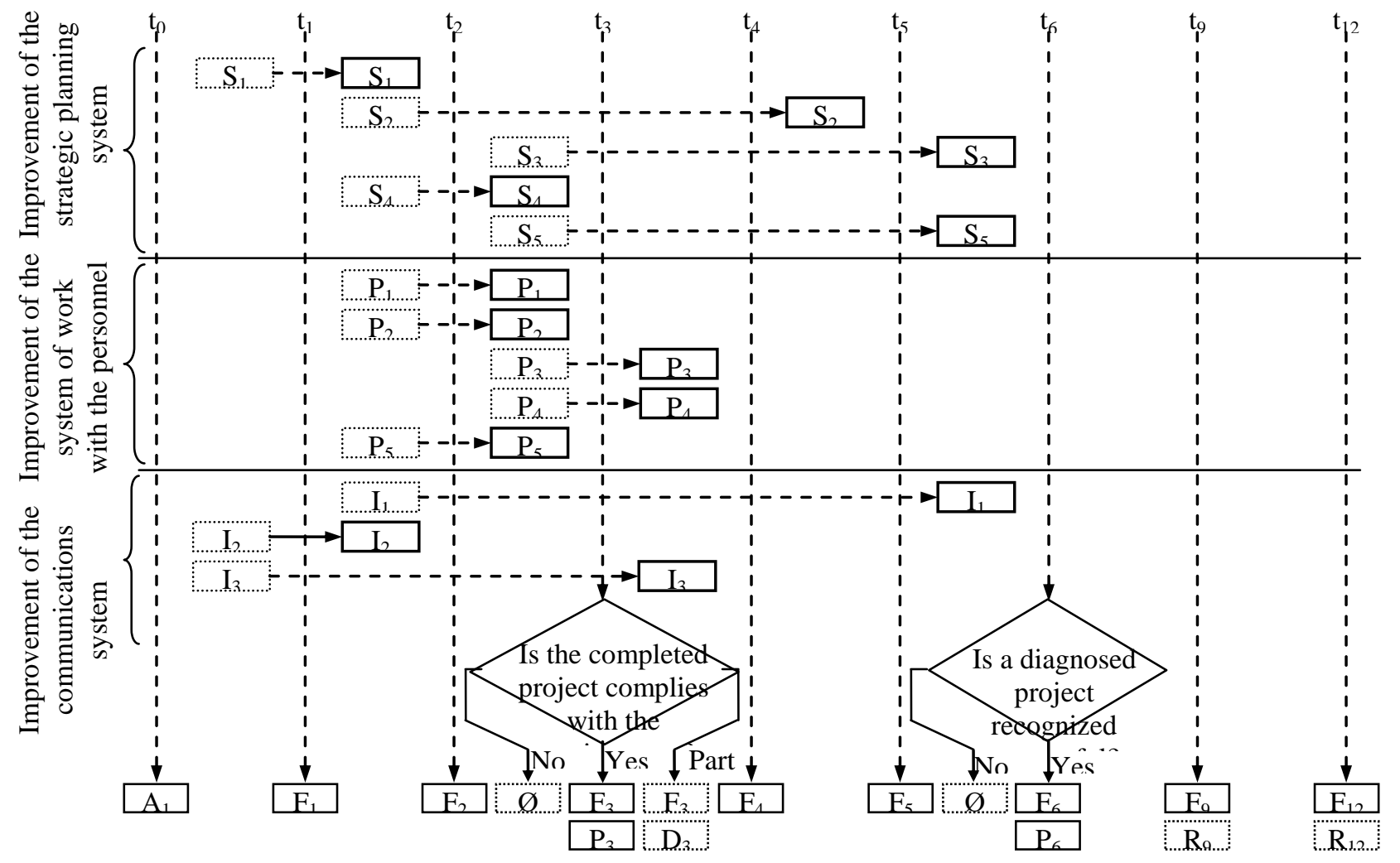

Legend:

$t_{i}$ - periods (months); $S_{i}, P_{i}, I_{i}$ - project elements for improving strategic planning, work with staff and communications systems; $A_{i}-$ advance payments; $F_{i}$ - fixed part of payment; $P_{i}-$ awards; $D_{i}-$ fines; $R_{i}-$ royalty; $\varnothing-$ termination of cooneration.

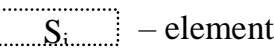 design;
$\mathrm{S}_{\mathrm{i}}$ - element introduction;
$\mathrm{F}_{\mathrm{i}}-$ basic payment;

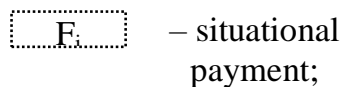

Fig. 2. The mechanism of payment for consulting services provided within the framework of an integrated project (for example, PJSC “Iskra")

\section{* Developed by the author}

After completing the design of all elements, the customer must conclude whether the consulting project meets its primary requirements. In case of a partial inconsistency, the performer must at his own 
expense fix the deficiencies and his payment may be reduced by imposing penalties. If the project does not fully satisfy the customer, the payment for the last period does not occur at all, despite the fact that some elements of the project can already be implemented. On this, the cooperation is simply stopped, and the work done at this time will be the basis for the formation of a new technical task for a new consulting project for the next performer. If the project meets all the requirements, then the performer must receive an additional bonus and continue to work on the implementation of the following elements. Such variation of payment stimulates the performer to work honestly, and clearly defined compliance criteria make it impossible for the customer to manipulate the purpose of artificially reducing payment for each calendar period.

Upon completion of the implementation of the consulting project (in our case, this period is $t 6-6$ months) there is a new diagnosis, on the basis of which the project is recognized as successful. If most of the criteria for success are not achieved, then this cooperation with the consulting firm ends, and without payment of the final fixed part of the payment (F6). If the project is recognized, the successful performer receives a bonus (F6 + P6) in addition to a fixed payment, after which the partners determine whether further management support is required from the executor. If such support is needed, then the consulting firm may receive fixed payments throughout the service period and / or claim a small percentage of royalties from the increase in profits received through the implementation of project activities. The decision on the form and method of payment of consulting services in the post-project period is taken on the basis of negotiations based on how the customer evaluates the possibilities for further growth of indicators provided that external consultants participate in their work. All described options for payment of consulting services should be stipulated in the final contract or an annex thereto, taking into account (if necessary) possible amendments to inflation, fluctuations of the exchange rates or the discount rate of the NBU. The consequence of multidimensional and iterative diagnosis of consulting projects is the need to determine the parameters of diagnosis and the choice of its performers. Regarding diagnosis options, the question is whether the methods, procedures and performance diagnostics consulting projects at its various stages are fundamentally different; to be quite simple make adjustments used performance evaluation. If we are talking about fundamental changes, will they be able to standardize and create a universal mechanism for diagnosing consulting projects for machine-building enterprises.

The selection of consultants for the diagnosis of consulting projects is a potential source of conflict between the interests of stakeholders. Participants in the process of diagnosing consulting projects (customer, performer, other interested parties) will likely have a different vision of their process and desired result, will use different criteria, have different competencies and will be guided by different (and not always explicit) motives. One more significant point: is there at the enterprisecustomer specialists who are able to diagnose the proposed consulting projects and choose them on an alternative basis? On the one hand, if managers of an enterprise are able to identify problems that are the basis for the involvement of consulting firms, then these same leaders obviously have ready-made criteria for selecting the proposed consulting projects. On the other hand, if necessary, you can attract a specialist who is not expert in a specific consulting project, who is an expert in the subject field. This will lead to additional costs, but will reduce the level of subjectivity of the decision to choose a diagnosed consulting project.

Conclusions drawn from the research and prospects for further investigation. Building application tools for diagnosing consulting projects engineering companies is based on identifying the mechanism of influence diagnosed projects for facilities management, their subsystems and components. The identification of the impact of diagnosed consulting projects on the activities of enterprises is the basis for further diagnosis of the results of projects implementation and economic evaluation of their implementation. Based on the analysis of possible payment options for consulting projects, a mechanism for payment of consulting services has been developed, which will allow finding a compromise of the interests of participants and avoiding threats of inconsistencies in payment for work performed. The prospects for further research are to develop a model for diagnosing the results of the implementation of consulting projects, which will include the choice of methods and methods of diagnosing, the allocation of alternative sets of business indicators, the establishment of economic and non-economic criteria for evaluating the effectiveness of consulting, as well as organizing the monitoring of indicators and automated processing of the results of the diagnosing of the consulting project. 


\section{REFERENCES}

1. Mel'nyk, O.H. (2010). Systemy diahnostyky diyal'nosti mashynobudivnykh pidpryyemstv : polikryterial'na kontseptsiya ta instrumentariy [Diagnostics systems of machine-building enterprises activity: multicriterion concept and toolkit]: monohrafiya [monograph]. Lviv: Vydavnytstvo L'vivs'koyi politekhniky. [in Ukrainian].

2. Verba, V. (2010) Konsaltynghovyj proekt: sutnistj, oznaky ta peredumovy uspishnoji realizaciji [Consulting project: the essence, signs and preconditions of successful realization]. Visnyk Khmeljnycjkogho nacionaljnogho universytetu [The bulletin of the Khmelnitsky National University] Vol. 4, no. 4, 274-280. [in Ukrainian].

3. Brintseva, O. H. (2010) Konsaltynhovyy proekt: sutnist', oznaky ta peredumovy uspishnoyi realizatsiyi [Estimation of Macroeconomic Efficiency of Human Resource Management Consulting]. Naukovyy visnyk Poltavs'koho universytetu ekonomiky $i$ torhivli. Seriya : Ekonomichni nauky [The scientific bulletin of Poltava University of Economics and Trade. Series: Economic sciences], no. 4(3), 210-213. [in Ukrainian].

4. Kuz'min, O.YE., Heorhiadi, N.H. (2006) Formuvannya i vykorystannya informatsiynoyi systemy upravlinnya ekonomichnym rozvytkom pidpryyemstva [Formation and use of the information management system by the economic development of the enterprise]: monohrafiya [monograph]. Lviv: Vydavnytstvo Natsional'noho universytetu L'vivs'ka politekhnika [in Ukrainian].

5. Bosak, A.O., Trevoho O.I. (2015) Ekonomichne otsinyuvannya ta rozvytok komunikatsiy v systemi upravlinnya intelektual'nym kapitalom pidpryyemstva [Economic evaluation and development of communications in the system of intellectual capital management of the enterprise]: monohrafiya [monograph]. Lviv: ST «Mis'ki informatsiyni systemy» [in Ukrainian]. 